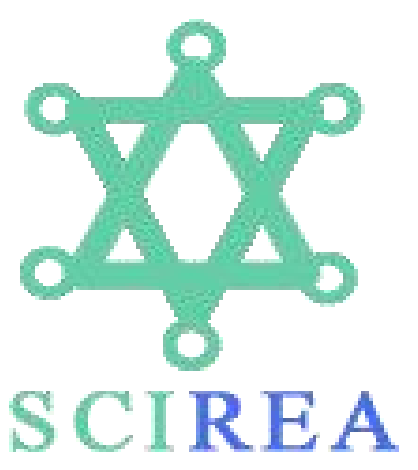

SCIREA Journal of Education

http://www.scirea.org/journal/Education

January 31, 2021

Volume 6, Issue 1, February 2021

\title{
BROWN at 67. From Chartergate to Segregate? School Resegregation in 2021.
}

\author{
Steven Michael Brown \\ Professor of Educational Leadership and Policy, The University of Texas Permian Basin, \\ USA \\ Email: drstevenmbrown@gmail.com
}

\begin{abstract}
65 years after the implementation of the Brown $v$ Board of Education landmark U.S. Supreme Court case decision on May 17, 1954, we once again have in the United States a large number of public schools that are racially segregated. The primary source of such resegregation is not because of judicial rulings, but is produced primarily due to demographics, based on where people live. Specifically, parents typically want their children to attend schools as close to where they reside. But, the question could also be asked, is it possible that this is occurring due to the dramatic increase of charter schools that have been created across our nation?

The question to be asked is: Is school segregation getting worse in 2021? Many people say yes, including scholars, journalists, and civil-rights advocates. For the first time in years, there's something resembling a consensus: Racially divided schools are a major and intensifying problem for American education-maybe even a crisis. And, charter schools are viewed as substantially contributing to this major problem.
\end{abstract}


Keywords: Segregation; Integreation; Brown v. Board of Education; Charter schools.

\section{INTRODUCTION}

65 years after the implementation of the Brown $v$ Board of Education landmark U.S. Supreme Court case decision on May 17, 1954, we once again have in the United States a large number of public schools that are racially segregated. The primary source of such resegregation is not because of judicial rulings, but is produced primarily due to demographics, based on where people live. Specifically, parents typically want their children to attend schools as close to where they reside. But, the question could also be asked, is it possible that this is occurring due to the dramatic increase of charter schools that have been created across our nation?

\section{BROWN V. BOARD OF EDUCATION OF TOPEKA: A QUICK SUMMARY}

On May 17, 1954, at 12:52 p.m., the United States Supreme Court announced its unanimous decision in the landmark case of Brown v. Board of Education of Topeka. That name was given to five separate cases that were heard by the U.S. Supreme Court concerning the issue of segregation in public schools. These cases were Brown v. Board of Education of Topeka, Briggs v. Elliot, Davis v. Board of Education of Prince Edward County (VA.), Bolling v. Sharpe, and Gebhart v. Ethel. While the facts of each case are different, the main issue in each was the constitutionality of state-sponsored segregation in public schools.

Chief Justice Earl Warren, who wrote the unanimous decision, said the following:

"Does segregation of children in public schools solely on the basis of race, even though the physical facilities and other "tangible" factors may be equal, deprive the children of the minority group of equal educational opportunities? We believe that it does.

We conclude that, in the field of public education, the doctrine of 'separate but equal' has no place. Separate educational facilities are inherently unequal. Therefore, we hold that the plaintiffs and others similarly situated for whom the actions have been brought are, by reason of the segregation complained of, deprived of the equal protection of the laws guaranteed by the Fourteenth Amendment.” (Brown v. Board of Education, 1954.) 
As a historical point of reference, 379 days later, on May 31, 1955, the U.S. Supreme Court had to reiterate its previous decision from 1954, with what is simply referred to as Brown II. The Court said:

"While giving weight to these public and private considerations, the courts will require that the defendants make a prompt and reasonable start toward full compliance with our May 17, 1954, ruling. Once such a start has been made, the courts may find that additional time is necessary to carry out the ruling in an effective manner. The burden rests upon the defendants to establish that such time is necessary in the public interest and is consistent with good faith compliance at the earliest practicable date.

The judgments below, except that in the Delaware case, are accordingly reversed and the cases are remanded to the District Courts to take such proceedings and enter such orders and decrees consistent with this opinion as are necessary and proper to admit to public schools on a racially nondiscriminatory basis with all deliberate speed the parties to these cases." (Brown II Decision, 1955.)

\section{THE NAACP CALLS FOR A BAN ON NEW CHARTER SCHOOLS IN THE U.S.}

In October of 2016, the National Association for the Advancement of Colored People (NAACP) called for a ban on new charter schools. This anti-charter proposal, which had the support of over 50 activist organizations, including Black Lives Matter, cited concerns over heavy-handed discipline and segregation they argued that charter schools promoted.

The following is an excerpt from the proposal that was ratified in October of 2016 by the NAACP Board of Directors:

Members of the National Association for the Advancement of Colored People (NAACP) Board of Directors ratified a resolution Saturday adopted by delegates at its 2016 107th National Convention calling for a moratorium on charter school expansion and for the strengthening of oversight in governance and practice.

While we have reservations about charter schools, we recognize that many children attend traditional public schools that are inadequately and inequitably equipped to prepare them for the innovative and competitive environment they will face as adults. Underfunded and undersupported, these traditional public schools have much work to do to transform curriculum, prepare teachers, and give students the resources they need to have thriving careers in a 
technologically advanced society that is changing every year. There is no time to wait. Our children immediately deserve the best education we can provide. (NAACP Board of Directors, 2016)

As with any decision in the area of education as well as politics, many people and groups agreed and disagreed with the NAACP's proposal. A nationwide media campaign created by "ChartersWork" was formed in response to a growing number of voices calling on the National Association for the Advancement of Colored People (NAACP) to reconsider the position it took to put a moratorium on charter schools.

Parents with children in charter schools, as well as those on waiting lists to get in, made their voices heard for parental choice and the positive impact charter schools are having on Black student achievement across the nation. Led by the Black Alliance for Educational Options and the National Alliance for Public Charter Schools, the new ChartersWork campaign tells a clear and compelling story of why more than 700,000 Black families have chosen charter schools.

A letter was sent to the NAACP signed by more than 160 Black education and community leaders from across the country, including Cheryl Brown Henderson, calling on the NAACP to reconsider and learn more about how charter schools are helping Black families. Cheryl Brown Henderson is the daughter of the late Reverend Oliver L. Brown, lead plaintiff in the Brown v. Board of Education case.

\section{DO PUBLIC CHARTER SCHOOLS IMPACT SCHOOL RESEGREGATION?}

Andre Perry, in a 2017 article written for The Hechinger Report, stated,

“Charter schools are among the nation's most segregated, an Associated Press analysis finds - an outcome at odds, critics say, with their goal of offering a better alternative to failing traditional public schools.

National enrollment data shows that charters are vastly over-represented among schools where minorities study in the most extreme racial isolation. As of school year 2014-2015, more than 1,000 of the nation's 6,747 charter schools had minority enrollment of at least 99 percent, and the number has been rising steadily.

The problem: Those levels of segregation correspond with low achievement levels at schools of all kinds. "Desegregation works. Nothing else does," said Daniel Shulman, a Minnesota 
civil rights attorney. "There is no amount of money you can put into a segregated school that is going to make it equal."

Shulman singled out charter schools for blame in a lawsuit that accuses the state of Minnesota of allowing racially segregated schools to proliferate, along with achievement gaps for minority students. Minority-owned charters have been allowed wrongly to recruit only minorities, he said, as others wrongly have focused on attracting whites." (Perry, 2017) Adding to the charter school impact on overall segregation in America's public schools is the overall racial discrimination which greatly contributes to the desegregation of our schools. A 2016 report from the U.S. Government Accountability Office entitled "K-12 EDUCATION:

Better Use of Information Could Help Agencies Identify Disparities and Address Racial

Discrimination, " uncovered and reported the following:

The percentage of K-12 public schools in the United States with students who are poor and are mostly African American or Hispanic is growing and these schools share a number of challenging characteristics. From school years 2000-01 to 2013-14 the percentage of all K-12 public schools that had high percentages of poor and African American or Hispanic students grew from 9 to 16 percent, according to GAO's analysis of data from the Department of Education

These schools were the most racially and economically

concentrated: 75 to 100 percent of the students were African American or Hispanic and eligible for free or reduced-price lunch — a commonly used indicator of poverty.

GAO's analysis of Education data also found that compared with other schools, these schools offered disproportionately fewer math, science, and college preparatory courses and had disproportionately higher rates of students who were held back in 9th grade, suspended, or expelled. (USGAO Report, 2016)

\section{IS SCHOOL SEGREGATION GETTING WORSE IN 2021?}

Many people say yes, including scholars, journalists, and civil-rights advocates. For the first time in years, there's something resembling a consensus: Racially divided schools are a major and intensifying problem for American education-maybe even a crisis. And, charter schools are viewed as substantially contributing to this major problem. 
There's also compelling numerical evidence as well. According to analysis of data from the National Center on Education Statistics, the number of segregated schools (defined as those schools where less than 40 percent of students are white), has approximately doubled between 1996 and 2016. In that same span, the percentage of children of color attending such a school rose from 59 to 66 percent. For African American students, the percentage in segregated schools rose even faster, from 59 to 71 percent. (Stancil, 2018)

The primary dilemma is that the nation's schools are evolving in many ways at once. Student populations undergo slow shifts; new schools are constantly opening and closing; attendance boundaries are drawn and redrawn. As a result, the effects of large-scale demographic change and those of local school policy get tangled up with one another. It can be hard for policymakers and researchers to separate one factor from the other.

According to a 2018 report by The Century Foundation, "Diverse by Design: Charter Schools, " five decades of research imply that racial and socioeconomic integration is one of the best design principles for creating successful schools that produce strong results for students and society. Students in diverse schools have higher average test scores and graduation rates than peers of similar backgrounds attending schools with concentrated poverty. The experience of learning in integrated classrooms alongside peers with different experiences, perspectives, and abilities helps to reduce racial bias and increase creativity, motivation, deeper learning, critical thinking, and problem-solving skills. (Halley \& Potter, 2018)

Supreme Court Justice Thurgood Marshall wrote, "Unless our children begin to learn together, there is little hope that our people will ever begin to live together." (Milliken v. Bradley, 418 U.S. 717, 1974)

Segregation by income very often moves in tandem with segregation by race. In addition to attending racially segregated schools, African American and Latino students are significantly more likely to attend high-poverty schools. The Civil Rights Project at the University of California, Los Angeles, calls this phenomenon "double segregation."

This report, however, emphasizes economic_rather than racial—segregation for a few reasons. Over the past decade, a growing number of schools and districts have integrated based on students' socioeconomic status rather than by race or ethnicity. Part of the reason for this shift is a recent U.S. Supreme Court opinion that suggested it may not be 
constitutionally sound for schools and districts to integrate solely based on students' race or ethnicity. Responding to this opinion, most school integration policies have shifted away from using race as a determining factor in student assignment.

In addition, schools that are economically integrated are also usually racially integrated. And, finally, integrating schools by income rather than race allows schools and districts to move beyond the negative public opinion of so-called forced bussing and other racially charged policies of the past. The Center for American Progress hopes that this report's focus on economic integration is reflective of current policies and practices and helpful for future stakeholders and policymakers.

However, in spite of numerous court battles and civil rights victories, racially segregated education never disappeared. In fact, during the 1990's, America's schools racially resegregated, which has left African American students more isolated than they were a generation ago. In fact, today, more than one-third of all students attend schools where at least 90 percent of their peers are of the same race or ethnicity.

One clear cause of this resegregation was the Supreme Court authorizing the termination of desegregation plans. Gary Orfield with the UCLA Civil Rights Project explains, "segregation increased substantially after [integration] plans were terminated in many large districts." Additionally, rapid growth of America's Latino population over the past decade has contributed to growing isolation of Latino students, often in high-poverty schools.

In a 2016 Civil Rights Project research brief, "Brown at 62: School Segregation by Race, Poverty and State," Orfield and his co-authors wrote that it has been a long time since the challenge of school segregation has been met with viable approaches to integrate schools by race, ethnicity, and income levels. (Orfield, et al, 2016)

According to Orfield,

"Instead, we have spent decades trying another approach: policies that have focused on attempting to equalize schools and opportunity through accountability and high-stakes testing policies, not to mention the federal subsidization of entirely new systems of school choice, like charter schools, without any civil-rights provisions. These policies have not succeeded in reducing racial segregation or inequality."

The project's last national look at charter schools, in 2010, found that racial and ethnic isolation of minorities is far more common in charter schools than traditional public schools. Seventy percent of African American students enrolled in charters attended schools deemed 
"intensely segregated." (The report defines such segregation as occurring when at least 90 percent of students were minorities.) This level of segregation was twice as high as in traditional public schools, the report said. The same analysis also found that half of Latino charter school students attended "intensely segregated" schools. Critics say the national data in the report are misleading, since so many charters serve inner-city neighborhoods."

"I don't think the effect of segregation is very much different between these two systems," Orfield said of charters and traditional public school districts. "The problem is, these are new schools. We're creating new segregated schools....In most of them, nobody's doing anything to make them diverse."

Orfield continues, "The Civil Rights Project has issued many reports on these enrollment changes and their impacts on segregation of schools across the country in the last 20 years. We have done that because of massive and growing research evidence that (1) segregation creates unequal opportunities and helps perpetuate stratification in the society and (2) diverse schools have significant advantages, not only for learning and attainment but for the creation of better preparation for all groups to live and work successfully in a complex society which will have no racial majority." (Orfield, et al, 2016)

Another clear cause of increased racial segregation was the decline in federal enforcement of court desegregation orders. During the 1970s and 1980s, for instance, the Nixon and Reagan administrations strongly opposed court-ordered busing - then a popular method of district integration - and weakened civil rights policies that would have promoted system wide desegregation plans.

The historical legacy of racial segregation also explains why students of color disproportionately attend economically segregated schools. For instance, African American and Latino students are five times more likely to attend high-poverty schools than white students. Recent census data also show that African American and Hispanic Americans live in poverty at more than twice the rate of non-Hispanic whites, and they are significantly much more likely to live in extreme poverty.

A large number of African American middle-class families also reside in low-income neighborhoods, and as a result, their children are more likely to attend low-income schools compared to white, middle-class families.

Expanding school choice through charter schools is among the top education priorities of the current federal administration, including U.S. Secretary of Education, Betsy DeVos, as well 
as many state legislatures. In his full budget proposal for fiscal year 2018, President Trump proposed to provide charter schools with an additional $\$ 158$ million, nearly a 50\% increase, while cutting the funds for the U.S. Department of Education by $13.5 \%$ or $\$ 9.2$ billion.

Amid this push to expand the charter sector, it is essential to understand how charter schools affect students who attend them, as well as the ways charter schools impact traditional public schools in their communities. In this report we focus on charter schools' contributions to racial and socioeconomic segregation of public schools, given that, as the nation's public school enrollment becomes increasingly diverse and multiracial, segregation is intensifying.

And of course, there's another reason to worry about school segregation, regardless of its cause: the problem of second-class citizenship. Ironically, this problem generates less discussion than technocratic concerns about test scores and income mobility. But it was pivotal in propelling the school-integration push of the 1960s and 70s, and for good reason. Civil rights advocates are not wrong to worry that, beyond any set of individual outcomes, it is not healthy nor sustainable for a society to effectively consign most children of color to an alternative system of schools.

None of these ills will heal themselves so long as segregated schools exist, or grow in number. And right now, such schools are growing in number, for reasons ranging from the benevolent to the reprehensible. Dedicated advocates and smart policymakers, including parents, can and must thwart school resegregation, and eventually reverse it. But it will not reverse itself. Action at all levels is needed to make it occur.

\section{IN CONCLUSION}

Public charter schools are hardly a cure-all when it comes to diversity, however, and current studies on the effects of the public charter school sector on segregation have been mixed. One study by Duke University found that more than two-thirds of charter school students receive their education in intensely segregated settings. Similar research suggests that expanding public charter schools may contribute to increased segregation without focused policy changes. (Ladd, et al, 2015)

As education experts from The Century Foundation Richard Kahlenberg and Halley Potter argue, "school policies in recruitment, location, and transportation can either diminish or drive charter school segregation. Some charters, for example, may be highly committed to 
diversity, but do not have much room to diversify because they are located in homogenous neighborhoods. “(Kahlenberg \& Potter, 2014)

The economic and racial makeup of most classrooms today fails to reflect the rapidly changing demographics of the nation. Although the United States is growing increasingly diverse, the diversity of its public classrooms remains stagnant.

The cultural divides existing across this country in 2021 can be greatly reduced if students are educated in socioeconomically diverse schools. Yet, in many ways, school integration continues to be a policy that nearly everyone supports but almost no one is pursuing. In addition, we must stop this ongoing battle over education for students of color.

Although the U.S. Supreme Court found 67 years ago in the Brown decision that segregated schools are inherently unequal, this principle has proven to be an inadequate motivation for school, district, state, and federal leaders to prioritize this issue. And the decades of research demonstrating the substantial benefits of school diversity have also proven insufficient to move most leaders to act.

It is well past the time for educational leaders to act on true and equitable integration of our public schools. School economic integration presents one of the most viable solutions to the inequities impacting the nation. It is hoped that the next important steps that occur will create an increase in school diversity and, ultimately, educational equity.

A final thought, offered more as a question: What will American education be like in 2029 when the title of a journal article will be, "Brown at 75: Where are we now?"

\section{References}

[1] Brown v. Board of Education, 347 U.S. 483 (1954).

[2] Brown v. Board of Education II, 349 U.S. 294 (1955).

[3] Kahlenberg, Richard D. \& Potter, Halley. (2014). “A Smarter Charter: What Works for Charter Schools and Public Education." The Century Foundation, August 7, 2014. New York. https://tcf.org/content/book/a-smarter-charter/

[4] Ladd, Helen, Clotfelter, Charles T. \& John B. Holbein, John B. (2015) “The Growing Segmentation of the Charter School Sector in North Carolina." Cambridge, MA: 
National Bureau of Economic Research. NBER Working Paper No. 21078, Issued in April, 2015.

[5] Milliken v. Bradley, 418 U.S. 717 (1974).

[6] National Association for the Advancement of Colored People (NAACP) Board of Directors. "Statement Regarding the NAACP's Resolution on a Moratorium on Charter Schools." October 15, 2016.

[7] Orfield, Gary, Ee, Jongyeon, Frankenberg, Erika, \& Siegel-Hawley, Genevieve. (2016). "Brown at 62: School Segregation by Race, Poverty and State." Civil Rights Project / Proyecto Derechos Civiles, UCLA, May 16, 2016. https://www.civilrightsproject.ucla.edu/research/k-12-education/integration-anddiversity/brown-at-62-school-segregation-by-race-poverty-and-state/Brown-at-62-finalcorrected-2.pdf

[8] Perry, Andrew. "Charter school leaders are complicit with segregation, and it's hurting their movement." The Hechinger Report, December 11, 2017/ New York. https://hechingerreport.org/charter-school-leaders-complicit-segregation-hurtingmovement/

[9] Potter, Halley \& Quick, Kimberly. "Diverse-by-Design Charter Schools." (2018). The Century Foundation, May 15, 2018. New York. https://tcf.org/content/report/diversedesign-charter-schools/

[10] Stancil, Will. (2018). "School Segregation is not a Myth." Atlantic Magazine, March 14, 2018. https://www.theatlantic.com/education/archive/2018/03/school-segregation-is-nota-myth/555614/

[11] United States Government Accountability Office (USGAO). (2016). “K-12 Education: Better use of information could help agencies identify disparities and address racial discrimination." April, 2016. https://www.gao.gov/assets/680/676745.pdf 